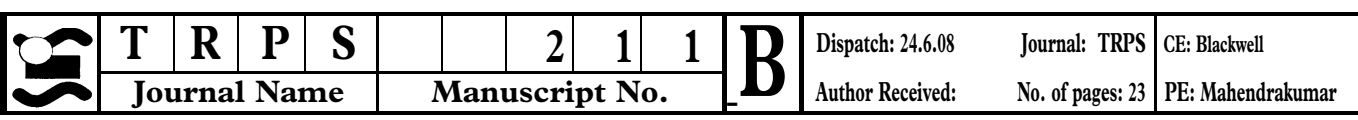

Transactions of the Philological Society Volume 106:2 (2008) 1-23

\title{
INTRODUCTION: IMPERSONALIZATION FROM A SUBJECT-CENTRED VS. AGENT-CENTRED PERSPECTIVE
}

\author{
By Anna Siewierska \\ Lancaster University
}

\section{Preliminaries}

The notion of impersonality is a broad and disparate one. In the main, impersonality has been studied in the context of IndoEuropean languages and especially Indo-European diachronic linguistics (see e.g. Seefranz-Montag 1984; Lambert 1998; Bauer 2000). It is only very recently that discussions of impersonal constructions have been extended to languages outside Europe (see e.g. Aikhenvald et al. 2001; Creissels 2007; Malchukov 2008 and the papers in Malchukov \& Siewierska forthcoming). The currently available analyses of impersonal constructions within theoretical models of grammar are thus all based on European languages. The richness of impersonal constructions in European languages, has, however, ensured that they be given due attention within any model of grammar with serious aspirations. Consequently, the linguistic literature boasts of many theory-specific analyses of various impersonal constructions. The last years have seen a heightening of interest in impersonality and a series of new analyses of impersonal constructions. The present special issue brings together five of these analyses spanning the formal/functional-cognitive divide. Three of the papers in this volume, by Divjak and Janda, by Afonso and by Helasvuo and Vilkuna, offer analyses couched within or inspired by different versions of the marriage of Construction Grammar and Cognitive Grammar as developed by Langacker (1991), Goldberg (1995, 2006) and Croft (2001). The paper by Kibort provides an analysis within Bresnan's (2001) Lexical Functional Grammar and the paper by Mendikoetxea elaborates further the analysis of impersonals currently being developed with Chomsky's (1995, 2000, 2005) Minimalist Program.

The different theoretical orientations of the papers go hand in hand with somewhat different approaches to impersonality, which, while not radically divergent, do not overlap entirely and, significantly,

(C) The author 2008. Journal compilation (c) The Philological Society 2008. Published by Blackwell Publishing, 9600 Garsington Road, Oxford OX4 2DQ and 350 Main Street, Malden, MA 02148, USA. 
provide different points of reference for the proposed analyses. Let me therefore contextualize the discussion in the five papers by outlining the two approaches to impersonality which they reflect.

\section{What IS AN IMPERSONAL CONSTRUCTION?}

The term impersonal, as used in the linguistic literature, has received both a structural and a communicative-functional characterization. From the structural point of view impersonalization is associated with the lack of a canonical subject, from the functional perspective with agent defocusing. ${ }^{1}$

Under the subject-based view of impersonalization, a canonical subject is one realized by a verbal argument which is fully referential and manifests the morpho-syntactic properties of subjects in a language. In terms of this subject-based approach, constructions which have been viewed as impersonal include: (a) those with a subject which is not fully referential, (b) those with a subject which does not display canonical subject properties, (c) those with a subject which is not a verbal argument but merely a place filler manifesting no semantic or referential properties, i.e. an expletive subject, and (d) those with no overt subject at all. Needless to say, given the controversies surrounding the notion of subject and its forms of expression, the efficacy of the above classification and the identity of the constructions within each of the four groups is very much theory dependent.

Impersonals of the first type, which are seen to have a subject but not a fully specified one, are typically identified with constructions in which a subject denotes a generic human or a loosely specified set of individuals. Such constructions come in a number of guises. One big sub-group embraces pronominalized subject constructions in which the non-referential subject is realized by a generalized noun or a personal pronoun used non-referentially. The generalized noun or personal pronoun may be a free form (e.g. man in German or they in English), a bound form (e.g. the proclitic $m \dot{t}$ in Northern Tepehuan, Bascom 1982:288, or the person inflection of null subject

\footnotetext{
${ }^{1}$ The third type of characterization frequently mentioned in the literature (see e.g. Lambrecht 1998; Bauer 2000; Siewierska 2007) is morphological, i.e. invariant marking of the verb for person. This characterization is, however, not applicable to languages which have no verbal person marking such as Mandarin and many other Sinno-Tibetan and Austro-Thai languages.
} 
(pro-drop) languages) or even phonologically null, as is uncontroversially the case in various Sino-Tibetan languages (with no person inflection on the verb) such as Dulong (1), Mandarin or Qiang.

ănbuu lāi-sā-ăjā
rice plant:NMLZ-DET

'It is not hard to plant rice.' mā-tuढà

NEG-be-difficult

(Dulong; Sun 1982: 164)

The second major subgroup of non-referential subject constructions with necessarily human referents consists of constructions in which the subject is identified (in one way or another) with nonpronominal morphology (arguably derivational morphology), for example, a reflexive marker, as in the case of Romance and Slavic reflexive impersonals (2) or a verbal affix such as $-(C) a k s e /-C i$ in Estonian (3), or $k \boldsymbol{k}$ - in rGygalrong (4).

(2) Si lavora sempre troppo.
si work:SG always much

'One always works too much.'

(Italian)

(3) Tollal loe-ti peamiselt ilukirjandust.

Then read-IMP:PAST mainly fiction:PART

'At that time one mainly read fiction.'

(Estonian; Torn-Leesik 2007: 3)

(4) $e-t \partial-k e-n^{n} g i ?-n \partial ?$ melen ke-z-nəsman re?

$I_{1 R}$-IRR 2 -IMP-be.ill- SUB without fail IMP-CAUSE-treat be necessary 'If one gets ill, it is necessary to treat him.'

(rGygalrong; J.T-S. Sun to appear)

In addition to impersonal constructions with non-referential human subjects, there are also those with subjects expressing natural forces or some other phenomena. The subject is identified with the person inflection on the verb, which is often third person neuter, as in the Russian (5).

$$
\begin{aligned}
& \text { Človeka ubilo. } \\
& \text { person:ACC kill:3SGN } \\
& \text { 'A person was killed.' }
\end{aligned}
$$


Impersonals of the second type, which have a subject but one displaying non-canonical encoding, are generally taken to include constructions featuring predicates expressing sensations, emotions, need, potential, in which the argument bearing the highest semantic role on the semantic-role hierarchy (with a given predicate) is an experiencer or cognizer. The relevant argument is typically marked dative, as in (6) from Icelandic, but may also occur in the genitive, as is the case in the Finnish necessity construction discussed in more detail by Helasvuo and Vilkuna (this volume), or even accusative, as is the case in Quechua (7).

$\begin{array}{llll}\text { Mér } & \text { likar } & \text { ágœetlega viđ hann. } \\ \text { Me:DAT like:3SG } & \text { well } & \text { with him:ACC } \\ \text { 'I like him.' } & & \text { (Icelandic; Barðdal 2005: 108) }\end{array}$
Nuka-ta-ka uma-ta nana-wa-n-mi.
me-ACC-TOP head-ACC hurt-OBJ-PRES-3-vAL

'My head hurts me.'

(Quechua; Hermon 2001: 151)

Also included in this group may be existential and locative constructions with non-canonical subject marking (and lacking an overt expletive subject). ${ }^{2}$ Two cases in point are illustrated in (8) from Finnish in which the subject is in the partitive case and (9) from Russian in which the subject is in the genitive. This genitive marking in Russian (and also Polish) is restricted to negative clauses.
Ulkona leikki
lapsia.
outside played:3sG child:PL:PART

'There were children playing outside.'

(9)
Deneg ne bylo.
money:GEN not be:3sGNEUT
'There was no money.'

Worth mentioning here are also constructions in which the non-canonical marking is dependent on the semantic properties

\footnotetext{
${ }^{2}$ Existentials with expletive subjects belong to group three, to be discussed below.
} 
of the subject. This is so with respect to instrumental marking of the subject in Sinhala (10) which according to Gair (1990) occurs only when the subject designates a collectivity or institution.

$$
\begin{aligned}
& \text { Aanduwe } \quad \text { at adaaro denəwa } \\
& \text { government-INSTR that:DAT support give } \\
& \text { 'The government gives support for that.' }
\end{aligned}
$$

(Sinhala; Gair 1990: 13,14)

The third type of impersonal occurs in languages which have overt expletive subjects. Such subjects are found in constructions which have no arguments available to function as subject and thus would otherwise lack a subject. This is what we find in impersonal passives of intransitive verbs, as in (11), and (some) constructions with meteorological predicates, as in (12).

$$
\begin{aligned}
& \text { (11) Es wurde getanzt. } \\
& \text { it become:PAST:3sG dance:PP } \\
& \text { 'There was dancing.' }
\end{aligned}
$$

$$
\begin{aligned}
& \text { (12) Bad. dimmer } \\
& \text { it darkening } \\
& \text { 'It is getting dark.' }
\end{aligned}
$$

Expletive subjects are also common in constructions in which the only candidates for subject are not encoded as such by virtue of their informational status in the discourse, as is the case in existentials (e.g. There are many linguists in Europe) and locatives (e.g. There's a man at the door) which have a presentation function or in the case of extraposed clausal arguments both finite (e.g. It is a pity that you can't come to the party) and non-finite (e.g. It is a pity to go home so early). In all of these constructions the verb, in languages which have verbal person marking, is in the third person singular or (when there is no distinction in number) in the third person.

With the exception of impersonal passives of both transitive and intransitive verbs and (some) constructions expressing weather phenomena (but see the discussion in the papers by Helasvuo and Vilkuna and also Kibort), the nature of the constructions 
belonging to group-four impersonals, those lacking a subject altogether, is the most theory dependent. Much rests on whether subjectless clauses are permitted by the theoretical framework in question, on the range of empty categories amenable to a subject analysis recognized and especially the tolerance of infinitival subjects. The most obvious candidates of subjectless impersonals are constructions with no obligatory nominal arguments or arguments which are more object-like than subject-like. An example of the former is the Polish impersonal modal construction built on the special indeclinable ex-verbs such as trzeba 'to be necessary' or wolno 'to be allowed' typically followed by the infinitive, illustrated in (13).

\section{(13) Wolno (nam) wracać do domu. allow (we:DAT) return:INF to home} 'One is allowed to return home.'/'We are allowed to return home.'

(Polish)

As shown in (13), the dative argument is optional, and it is not completely clear whether it is an argument of the modal element wolno or the infinitive, or both (see Słon 2003 for an illuminating discussion). The precise structure of two similar constructions in Russian is discussed in the paper by Divjak and Janda. Two constructions which have an obligatory argument which is more object-like than subject-like are the Finnish emotive causative construction shown in (14), which is more fully discussed in the paper by Helasvuo and Vilkuna, and the Polish construction with an infinitive and accusative NP illustrated in (15), which receives consideration in the paper by Kibort.

(14) Minu-aharmi-tta- $a \sim$ pelo-tta- $a \sim$

I-PAR annoyance-CAU-3SG

aivastu-tta-a.

fear-CAU-3SG $\sim$ sneeze-CAU-3SG

'I am annoyed $\sim$ scared $\sim$ I feel like sneezing.' (Finnish)

(15) Czuć wiosnę.

feel:INF spring:ACC

'One can feel spring (in the air).'

(Polish) 
Turning to the agent defocusing view of impersonalization, the agent is here understood rather broadly, as the causal participant of an event, and is also referred to as the actor, instigator or initiator. ${ }^{3}$ In what follows, I use the term instigator. The notion of defocusing is used in the sense of diminishing the prominence or salience from what is assumed to be the norm or, in the terminology of Langacker (1991), archetype. The defocusing may involve (a) the nonelaboration or under-elaboration of the instigator, (b) the demotion of the instigator from its prototypical subject and topic function or (c) both demotion and non-elaboration. Given the direct mention of subjecthood in the above characterization of impersonality, there is a considerable degree of overlap in the range of constructions which emerge as impersonal under the subject-based and instigatorbased characterizations of the term. The constructions which are seen to have a non-elaborated or under-elaborated instigator correspond to those lacking a fully referential subject. These are the impersonals of group one and those in group four which, in the absence of an overt referential argument, convey a generic or a pragmatically specified human agent, as is the case in both (13) and (14). The demotion of the instigator from subject covers the other impersonals of groups two, three and four with the exception of those not depicting events and thus lacking an instigator, i.e., the presentative existential and locative impersonals. These last constructions are at best considered to be on the very margins of impersonality under the instigator defocusing view. The third possibility, demotion and non-elaboration, relates to a construction not mentioned above, namely the agentless passive (see below).

In the majority of cases, it is fairly clear which of the above three instigator-defocusing strategies is at play in any given impersonal construction. Nonetheless, in some instances it is difficult to decide whether an obliquely marked argument corresponds to a defocused instigator or rather should be seen as an additional participant of the event. In the Polish constructions in (16) and (17), for example, the urine and smell may be considered to be the defocused instigators, or the instigator may be taken to be a necessarily unelaborated 'something' corresponding to the third-person singular marking of the verb.

\footnotetext{
${ }^{3}$ The actor, initiator or initiator may but need not be conceived of as an actual macro-role.
} 
(16)

$W$ tym domu cuchnie moczem.
in this house stinks:3sG urine:INSTR
'In this house it stinks of urine.'

(17)
$M d l i$
mnie
od
tego
zapachu. nauseates me:DAT from this:GEN smell:GeN 'This smell makes me nauseous.'

The former analysis is the one developed by Divjak and Janda in their paper in this volume and, by and large, also by Kibort in her contribution. Under Kibort's analysis, however, the third-person singular marking on the verb in such clauses may indicate an unelaborated 'something' if there is no other overt expression of the instigator. Such clauses would then qualify as impersonal by virtue of the non-elaboration of the instigator. In the case of (16) and (17), under Kibort's analysis just as under Divjak and Janda's, the impersonality is a function of instigator demotion.

\section{Differentiating BetweEn the SUBJeCt-CENTRED AND AGENT-CENTRED PERSPECTIVES}

Despite the high degree of overlap in the range of constructions which are identified as impersonal under the subject-based and instigator-based characterizations of the term, there are important points of difference between the two. First of all, the instigator defocusing approach adds to the set of impersonal constructions those in which an argument other than the instigator has been selected for subject in preference to the instigator. Most notably such constructions include personal passives, both agentless ones and those with an agent. Two other constructions displaying similar atypical subject assignment to a non-instigator rather than to the instigator are locative subject clauses (e.g. The garden is swarming with bees), and constructions with predicates expressing sensation, emotion, need, potential, possession, etc., such as the one in (18).

$\begin{array}{ll}\text { (18) Honum trytur } & \text { peningur. } \\ \text { him:DAT lacks:3sG } & \text { money:NOM } \\ \text { 'He lacks money.' } & \end{array}$

(Faroese; Bardal 2001: 108) 
Constructions like the one in (18) are similar to the one in (6) illustrated earlier both with respect to the type of predicate with which they occur and the presence of an argument in the dative, the major difference being that the dative argument in (18) is less amenable to a subject analysis than the one in (6) in view of there being another argument manifesting subject properties. In terms of the subject-based approach to impersonals, none of the constructions just mentioned is typically regarded as such.

The second important difference between the two approaches to impersonalization is that the subject-based approach is not in principle dependent on the agentivity of the absent canonical subject. I have already mentioned one reflex of this, the impersonal treatment of constructions which do not involve an instigator, namely existential and locative constructions performing a presentative function and constructions with extraposed clausal complements. Another less frequently discussed consequence relates to ergative or split ergative languages in which the transitive subject may be identified not with the instigator but rather with the patient. In such languages, the subject-based definition of impersonals identifies as impersonal constructions with a non-fully specified or non-canonically marked patient and a fully specified ergatively marked agent. Such constructions are referred to by Lazard $(1994,1998)$ as anti-impersonals, by analogy with anti-passives. Two cases in point from Basque are illustrated in (19), taken from Creissels (2007: 38).
a. Bilbon
ikasi
$d u t$
Bilbao:LOC learn:PFV
'I studied in Bilbao.'
b. Otsoak ardiari esetsi zion
wolf:ERG sheep:DAT attack:PFV AUX:PAST.P:A3sG:D3sG
'The wolf attacked the sheep.'
(Basque)

In (19a) the $\mathrm{P}$, the subject studied, indicated by the agreement marking on the auxiliary receives a non-specific reading corresponding to that of the English translation. (The clause is also open to a definite interpretation.) In (19b) the $P$, the sheep, receives atypical dative rather than absolutive marking. Thus if the subject in Basque is identified with the patient rather than the agent, the subject is a non-referential one in (19a) and a non-canonical one in (19b). The construction in (19a) can thus be seen as corresponding 
to the pronominalized subject impersonals in null-subject languages of group one, and that in (19b) as corresponding to the non-canonical subject impersonals of group two. Under the instigator-based approach, the examples in (19) are evidently not impersonal. Within the context of the subject-based approach, the relevant constructions can be excluded from the domain of impersonality, if being an instigator is taken to be a property of canonical subjects. However, in order to achieve this and simultaneously avoid intransitive unaccusative clauses (e.g. The children arrived) from being treated as impersonals, a canonical subject would have to be identified with the highest available argument on the semantic-role hierarchy occurring with a given predicate. Such a merger of the subject-based and instigator-based approaches does away with the Basque constructions, but also incorporates passives, locative subject constructions and subject-inversion constructions (e.g. In the garden stands a fountain) into the structurally based domain of impersonality. It is thus not without consequence.

The third way in which the subject- and instigator-based views of impersonals differ is that under the instigator-defocusing approach impersonality is not associated solely with elements of or operations on argument structure or even necessarily tied to constructions. Impersonality is conceived of more widely as involving speakerchoice with respect to the construal of an event and is seen to be sensitive to the effects of discourse. Thus, anticausatives (e.g. The vase broke) qualify as at least borderline impersonals in terms of agent defocusing, since an event which could have been construed as involving an instigator (e.g. Did you break the vase?) is depicted as not involving one (No, it just broke.). Structurally, however, anticausatives are not impersonal owing to the fact that the only available argument is the subject. Another group of constructions which may be classed as impersonal in terms of instigator defocusing are action nominalizations (e.g. the circling of the camp by the tribe). Action nominalizations focus on a process at the cost of the participants involved in that process. While not only instigators but also patients may be affected, the instigator is commonly omitted in nominalizations (e.g. the circling of the camp) while the patient often cannot be omitted unless the instigator is also elided (*the circling by the tribe). Nominalizations, like passives, can thus be treated as a means of instigator omission. They are not, however, considered to be impersonal constructions 
from the structural point of view. Interestingly, J.T-S Sun (to appear) reports that in a cluster of closely related Tibeto-Burman languages of Sichuan, the rGyalrongic languages, nominalizing affixes on the verb are used in impersonal constructions to convey a generic human agent, as in (4). It is also worth noting that the translations into English of impersonal passives of intransitive verbs involve a nominalized form of the verb, as shown in (11). Yet another set of constructions which may acquire an instigatordefocusing function in wider discourse-pragmatic context are existentials. They will be discussed more extensively in section three with reference to the article in this volume by Afonso, which is devoted to the impersonal use of existentials.

The last significant difference between the subject-based and instigator- defocusing-based approaches to impersonalization that needs to be mentioned is that instigator defocusing, unlike the presence versus absence of a subject, is a matter of degree. Thus analyses of impersonalization in terms of instigator defocusing tend to be strongly concentrated on elaborating degrees of impersonality. This is particularly evident in analyses couched within the Construction Grammar and Cognitive Grammar traditions in which categories are viewed in terms of their prototype structure, owing to the fact that not only defocusing but also the category of instigator is itself scalar. Consequently, instigator defocusing may be quite nuanced and interpreted along more dimensions than under other approaches: with respect to verbal argument structure, with respect to the prototypical transitive event in terms of which the archetypal instigator is identified (Langacker 1991,238), with respect to degrees of referentiality and specificity, and with respect to grammatical encoding. Thus, for example, in terms of argument structure a distinction can be made between the degrees of instigator defocusing shown in (20), correlating with five types of impersonal: those with an instigator subject which is not fully referential (the generic and arbitrary subject impersonals), those with a demoted instigator which maintains argument status and is obligatory (the experiencer subjects of emotive and psychological predicates), those with a demoted argumental instigator which is optional (the optional experiencer of, for instance, Russian and Polish root infinitives), those with a demoted instigator which loses argument status (passives both personal and impersonal) and those without any instigator (anticausatives). 
(20) focal argument $>$ under-elaborated argument $>$ demoted obligatory argument $>$ demoted optional argument $>$ demoted non-argument $>$ no argument

Another scale of impersonality, relating to the dimensions of transitivity and grammatical encoding is discussed in Divjak and Janda's contribution to this volume.

While impersonalization is less tied to subjecthood under the agent-based approach than under the subject-based one, in the actual analyses of impersonal constructions in theoretical models of grammar of all persuasions the nature of the subject plays a crucial role. As one would expect, particularly challenging is the analysis of the wide variety of impersonal constructions with covert subjects, listed above in either group one or four. At issue is in the first place the existence of a covert subject, once it is assumed to exist, its precise nature, and then the formal mechanisms via which it can be represented which would reflect the structural and semantic differences obtaining between the various constructions. Some idea of the structural differences can be gathered from the pre-theoretical discussion above. The semantic differences include: the necessarily human versus inanimate nature of the covert subject, its person, number and gender features, its referential interpretation with respect to the inclusion of the speaker and hearer, its openness to generic versus existential readings and the cognitive accessibility of its referents. All of these semantic differences also receive due attention in the contributions to this special issue, to which I now turn.

\section{The FiVE CONTRIBUTIONS}

The first contribution to this special issue, Ways of attenuating agency in Russian by Divjak and Janda, deals with two of the controversial and apparently subjectless impersonals of group four, which have also been analysed as having a subject, an infinitival one by some, and a dative one by others. The constructions in question illustrated in (21) are similar to the Polish example in (13) and feature a finite verb in the third-person singular neuter and an infinitive plus often an accompanying NP in the dative case as in $(21 \mathrm{a}, \mathrm{b})$ or, less frequently, in the accusative case. 
(21)
a. Devuske nadoelo sit.
Girl:DAT bore:3SGN sew:INF
'The girl got sick of sewing.'
b. Vam
nadležit
vstretit' $\dot{e} t u$
you:DAT be required:3sG
meet:INF that:ACC
nuždu.
need:ACC
'You have to meet that need.'

Divjak and Janda argue that despite the superficial structural similarity of (21a) and (21b), they are in fact instantiations of two distinct constructions. Under their analysis the verb nadoest 'to bore' in (21a) is a full verb with normal argument-structure properties and takes an argument in the nominative and an optional experiencer argument in the dative. The nominative argument may be realized by a referential entity but also by an infinitive, as in (21a). In the latter case the non-prototypical choice of filler by an event rather than a referential expression is indicated by the obligatory third-person singular neuter marking of the verb, which the authors interpret not as default marking but as a reflection of the reification of the event as a thing. The verb nadlezit' 'to be required' in (21b), by contrast, is treated by Divjak and Janda as a defective verb lacking the ability to take arguments. It cannot, however, stand alone and thus requires the presence of the infinitive. The defective verb and infinitive thus form a complex event and, unlike in (21a), there is no reification. As for the dative NP, this is the subject of the infinitive which owing to the presence of the defective verb is marked dative rather than nominative, the case of the subject in Russian. Semantically, this dative argument is thus not a experiencer, as in the case of the dative argument in (21a) but rather what Divjak and Janda call an agent experiencer, as it is the agent of the activity specified by the infinitive and the experiencer of the modality imposed by the defective verb. Significantly the initiator of the modality expressed by the defective verb is absent from the argument structure altogether.

In sum, according to Divjak and Janda's analysis the construction in (21a) is not in fact subjectless but has a subject, albeit a highly atypical non-human and inanimate one expressed by the infinitive. It thus qualifies as impersonal not by virtue of lacking a subject but rather by virtue of instigator defocusing, i.e. the event rather than the instigator being assigned the subject function. The construction in 
(21b), on the other hand, does lack a subject. It also involves instigator defocusing of two types. The entity imposing the modality expressed by the defective verb is defocused by virtue of being absent from the argument structure altogether, while the initiator of the action carried out by the infinitive is non-canonically marked. In terms of their three degree scale of impersonalization, the construction in (21b) emerges as lower in degree of impersonality than the one in (21a), since an agent experiencer is viewed by them as being closer to a prototypical agent than an experiencer.

The article by Afonso, Existentials as impersonalising devices: the case of European Portuguese, focuses on the haver construction in European Portuguese, which is associated in Romance linguistics primarily with existential and presentative usage. Although the haver construction is typically regarded as impersonal under the subject-based approach, but not under the instigator-defocusing one, Afonso argues that it may in fact acquire an agent-defocusing function by virtue of the discourse context.

Building on Ziv's (1982) impersonal analysis of certain uses of the non-deictic there construction in English, Afonso distinguishes three types of impersonal use of the haver construction in European Portuguese. The first of these is the action nominal haver construction in which the coda is an action nominal or nominalization. As mentioned earlier, action nominals may be viewed as a means of instigator defocusing by virtue of the fact that they focus on a process at the cost of the participants in an event, which are either not expressed at all or potentially in an adjunct phrase. This action nominal impersonal use of haver, like that of English there constructions, emerges in certain discourse contexts, such as the one in (22) where the haver construction (in bold) is preceded by two instances of the impersonal se construction.

Olhe conversava se talvez se vivesse uma vida
look:3sg speak :3s se maybe live:3sg a life
melhor que agora viva se melhor.
better than now live:3sg se better
Talvez houvesse mais dialogo
maybe there:be:3sg more dialogue
'Well, one talked, maybe one lived a better life than
nowadays, one lived better. Perhaps there was more
dialogue,'


Afonso points out, that in the absence of the preceding two se constructions, the haver construction could be seen as presentative, i.e., as introducing a new discourse topic (the nature of the dialogue engaged in by people in the past), rather than as downgrading the active involvement of the speaker as an instigator in the described event. In other words there is nothing in the part in bold in (22) which in itself would induce an impersonal reading. The impersonal reading is a function of the interaction of the construction with the discourse context.

The second type of impersonal haver construction distinguished by Afonso downgrades the actor by focusing on the property rather than the action of an event. It features a coda expressing a property which is encoded by a de-adjectival noun and is therefore referred to by Afonso as the de-adjectival haver construction. In the third type of impersonal haver construction the defocusing of the actor is achieved via focusing on another participant in the event, or its circumstances such as location or time and is termed by Afonso the focused non-agentive entity impersonal haver construction.. It is important to note that the third type of impersonal usage is seen to be even more strongly dependent on the context of the utterance than the action nominal and the deadjectivial types as there is no structural element in the construction, such as a nominalization, to formally deflect attention from the actor. This is achieved solely via the discourse context. Needless to say, the context dependence of the impersonal interpretation of the haver constructions and in particular of the focused non-agentive entity impersonal haverconstruction is viewed by Afonso as an argument for extending the notion of construction from a pairing of form and meaning (meaning in the wide sense of the term incorporating semantic and pragmatic meanings), as originally conceived of by the founders of Construction Grammar, to a triumvirate of form-meaning and context of use.

The article by Helasvuo \& Vilkuna, Impersonal is personal: Finnish perspectives, provides an overview of impersonal constructions in Finnish which highlights their use, somewhat paradoxically, in denoting human participants. In terms of what in the Finnish linguistic tradition is referred to as unipersonality, i.e., invariant marking of the verb for person, there are at least seven constructions in Finnish which may be seen as impersonal. These range from the often discussed impersonal passive in (23) which also meets all 
the other criteria used in the determination of impersonality (lack of an overt grammatical subject, instigator-defocusing, and nonelaboration), to possessive constructions which merely exhibit an atypical distribution of subject properties: the possessor bears locative marking and the item possessed is in the nominative.

\section{(23) Sinu- $t$ valit-tiin. you-ACC choose-PASS.PAST \\ 'You were elected.'}

In all of these constructions with the exception of weather impersonals the defocused primary argument is necessarily or typically human. This holds both for the constructions which do not permit the overt expression of the defocused primary argument (the impersonal passive, the zero construction) and those in which it can occur in an oblique case, such as the genitive (the necessity and retrospective constructions), the partitive (the emotive causative construction), as illustrated in (14), or adessive (the possessive construction). Moreover, in some of these constructions the defocused human participant is typically the speaker and/or addressee or a recently mentioned discourse participant. This is so both in what Helasvuo \& Vilkuna call the retrospective construction, built on the verb tulla 'to become' and a form of the past passive participle and the zero construction featuring a verb in the third- person singular, illustrated in (24).

$\begin{array}{lllll}\text { Jos } & \text { osta- } a & \text { uude- } n & \text { konee- } n & \text { ilman } \\ \text { if } & \text { buy-3SG } & \text { new-ACC } & \text { computer-ACC } & \text { without }\end{array}$

käyttöjärjestelmä-ä, $\quad$ mitään $\quad$ ei operating.system-PAR nothing.PAR NEG:3SG tapahdu.

happen.CONNEG

'If one buys a new computer without an operating system, nothing happens.'

The zero construction, also mentioned in the paper by Mendikoetxea, is especially interesting since it provides an important contrast with the impersonal passive in (23), the passive versus active status of which has been the subject of considerable debate (see especially Blevins 2003). Helasvuo \& Vilkuna argue that while 
both constructions are used exclusively for situations involving human participants which are obligatorily left unexpressed, they differ structurally precisely in regard to the syntactic status of the unexpressed participant. That this is indeed so is suggested by a well known case-marking peculiarity of Finnish nominal objects (as opposed to objects which are personal pronouns) which bear accusative case only if there is another nominative argument present in the clause, and otherwise occur in the nominative case. We see that in the zero construction in (25) uuden koneen "new computer' occurs in the accusative case while in the impersonal passive in (23) kone 'machine' is in the nominative.

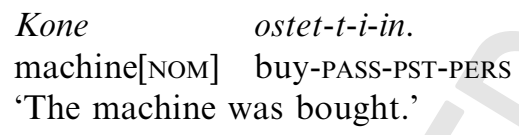

This suggests that while in the passive the human participant is removed from the syntactic argument structure, in the zero construction it is merely suppressed. Helasvuo \& Vilkuna rightly point out that under an active rather than a passive analysis of (23), this contrast between the two constructions would elude explanation.

The article by Kibort, Impersonals in Polish: an LFG perspective, addresses the issue of the morpho-syntactic status of the subject in a subset of the impersonal constructions in Polish within the confines of Bresnan's LFG. All of the constructions in question lack an overt lexical or pronominal structural subject and fall into group one or four of impersonals in the classification that I used in section two. Kibort divides them into three types according to how the apparent lack of the structural subject could be formally dealt with in LFG.

The first type are called pro-drop constructions since Kibort sees them as analysable in terms of the same mechanism as used for absent pronouns accompanying bound person markers on the verb. The constructions in this group, two of which were illustrated earlier in (16) and (17), express either weather phenomena or natural forces, involuntary bodily sensations or other sensory experiences and often have an adversative flavour. They feature a verb in the third-person singular and convey an inanimate as opposed to an animate instigator, which may in some instances be expressed in an oblique phrase, at least under some analyses (see the discussion earlier above). Kibort argues that the subject of all these 
impersonals is simply the indefinite cos' 'something', and thus all may be seen to involve pro $_{\text {-Indef }}$-drop.

Impersonals of the second type, which Kibort calls morpholexical, have a necessarily human subject indicated by non-pronominal morphology, i.e., the no/to participle, or the reflexive sie plus the third-person singular neuter form of the verb. Kibort's analysis of these constructions reflects the standard Polish approach which sees them as preserving the syntactic and semantic argument structure of the basic predicate without the possibility of expressing the instigator. Curiously, though, the instigator is by no means necessarily generic. In fact much more often than not it corresponds to a referent high on the accessibility scales in the sense of Ariel (1991). This is especially so in the no/to participle construction (see especially Słon 2003). The LFG analysis which Kibort proposes is to view the covert subject in both constructions as a pronominal anaphor as in the case of the 'missing' subject of non-finite clauses, [Pred 'Pro'], corresponding to PRO in Chomskian theory.

The third type of impersonal is seen by Kibort to lack a subject at all levels of structure, argument structure, functional-structure and constituent structure. There are two constructions which she considers as falling under this type, both conveying a necessarily human instigator, those with a small set of defective (non-inflecting) verbs and an argument in the accusative, illustrated earlier in (15) and impersonal passives of intransitives, such as those shown in (26).

$$
\begin{aligned}
& W \text { tym pokoju byto już sprzatane. } \\
& \text { in this room was:3sG:NEUT already clean:PASS P. } \\
& \text { 'There has already been cleaning of this room.' }
\end{aligned}
$$

The impersonal passive in (26) seems to be a characteristic essentially of the spoken language and as such has not received much attention in the Polish linguistic literature. It is formed using the auxiliary byc and the passive participle. The agent may occasionally be expressed in the form of a prepositional phrase, but as pointed out by Kibort, this occurs much less frequently than with personal passives. For the defective verbs Kibort proposes lexically impersonal argument structures, i.e., argument structures lacking a subject argument altogether. For the impersonal passives of intransitives, she suggests oblique function assignment to the 
only available argument. The necessarily human interpretation of both constructions may presumably be attributed to pragmatic convention along the lines suggested by Kański (1992) (see below). Kibort's subjectless analysis of the third type of impersonals runs counter to the LFG Subject Condition which requires all finite clauses to have a subject. This requirement, Kibort argues, needs to be abandoned. The default mapping of arguments to grammatical functions can then be expressed directly in terms of the LFG markedness hierarchy.

The last article in this collection, Clitic impersonal constructions in Romance: syntactic features and semantic interpretation, by Mendikoetxea offers an analysis of the syntax and semantics of the well known si/se constructions illustrated in (2) (and also in (20)) within the context of Chomsky's (1995, 2000, 2005) Minimalist Program. The analysis is inspired by the desire to provide, on the one hand, an invariant interpretation of si/se in its impersonal and passive uses and, on the other hand, a unified account of impersonal si/se and other impersonal constructions with a non-fully referential human subject. Mendikoetxea takes the view that si/se is a pronominal subject agreement clitic rather than, say, a valencyreducing particle or case absorber in both personal and impersonal si/se constructions and is not personless, as argued by Burzio (1986), but rather has an unspecified (zero-person) feature which is non-referential, along the lines of Kayne (1993). These two assumptions allow her to develop a coherent analysis of the impersonal si/se construction within the constraints of Minimalism. The key elements of this analysis are a si/se induced non-referential interpretation of the verbal inflection and the filling of the subject position not by referential pro, the empty category which occupies the subject position in pro-drop constructions of null subject languages, but rather by $\mathrm{G}$ (eneric)-pro. The G-pro is seen to be deficient in $\phi$ features, having a number feature but no person feature. Formally, the lack of person features of the G-pro enables it to be merged with the non-referential Agr(eement) features of the verbal inflection induced by the presence of si/se. Semantically, the lack of person features accounts for the fact that the subject of impersonal si/se constructions may be interpreted as arbitrary in reference.

Having G-pro in the subject position of the impersonal si/se construction makes this construction structurally very similar to 
impersonal pronominalized subject constructions. While these constructions may have an overt subject, such as man/on/one or they, or a bound or even a null one, the non-referential interpretation of the subject suggests that they too may be seen as having a non-referential person feature. If so, this raises the question of why some languages use one set of constructions to express non-fully referential human reference while others use another. Mendikoetxea pursues a line of explanation developed by Holmberg (2005; to appear) which relates the availability of different sub-types of the relevant impersonal construction in a language to the status of null subjects in that language. Simplifying somewhat, Holmberg argues that non-referential subjects in strictly non-null-subject languages such as English or French should receive overt pronominal realisation, those in partially null-subject languages (where first and second person can be null but a definite third person cannot) such as Finnish or Brazilian Portuguese should receive null realisation (no danger of a referential interpretation arises) and those in strict null-subject languages such as Spanish or Italian should be realized by verbal or other non-pronominal morphology (without which a referential reading would emerge). This three-way typology makes correct predictions, for the languages mentioned above, under the assumption that only in partially null-subject languages is the presence of a null pronominal in the subject position sufficient for the construction to be interpreted as impersonal. (Holmberg considers the subject of si/se constructions to be $s i / s e$.) Mendikoetxea, however, not only takes si/se constructions to have an empty subject position but also, man/on constructions the man or on of which she sees as being a pure expletive, following Egerland (2003). Therefore in order to capture the differences observed by Holmberg, she conditions the presence of G-pro in non-null-subject languages to the existence of an overt category which technically can enter into a checking relationship with the relevant Extended Projection Principle (EPP) features on $\mathrm{T}$ (ense). The G-pro in si/se constructions is of course (indirectly) licensed by the si/se.

In relation to the semantics of si/se constructions, Mendikoetxea makes two interesting suggestions. The first relates to the necessarily human interpretation of the referents of si/se impersonals, the second to the quantificational properties of their subjects. Following Kański (1992), she attributes the former to a pragmatic convention, 
whereby individual variables not restricted to any particular domain confine the universe of discourse to human individuals and even to discourse participants. As for the well known quantificational properties of the subjects of si/sei constructions, i.e., their ability to be open to a quasi-universal and quasiexistential reading, Mendikoetxea argues that this follows from their being similar to indefinite NPs. Thus, unlike Cinque (1988) and others, Mendikoetxea does not tie the existential versus universal readings to the presence versus absence of specific time reference but rather to the presence of a locational element which can restrict the variable introduced by G-pro. (A yet different explanation for the two readings is developed by Alonso-Ovalle (2002.)

As suggested by the above, the five contributions cover an impressive range of impersonal constructions, many of which have not been previously discussed in the general, as opposed to language-specific, linguistic literature. The different theoretical perspectives adopted by the authors highlight different facets of the investigated constructions, which provides a better picture of the existing variation within the domain of impersonality than would be achieved from a single theoretical position. It is hoped that the analyses presented will contribute to further developing cross-linguistically applicable accounts of impersonal constructions within the discussed theoretical frameworks and beyond.

\section{Department of Linguistics and English Language}

Lancaster University

Lancaster LA1 4 YT

United Kingdom

Email:A.Siewierska@lancaster.ac.uk

\section{REFERENCES}

Aikhenvald, Aleksandra, Y. R.M.W. Dixon and Masayuki Onishi (eds), 2001. Non-canonical marking of subjects and objects. Amsterdam: John Benjamins.

Alonso-Ovalle, Luis, 2002. 'Arbitrary-pronouns are not that indefinite'. in C. Beyssade, R. Bok-Bennema, F. Drijkoningen \& P. Monachesi (eds), Proceedings of Going Romance 2000, Amsterdam: John Benjamins, 1-14.

Ariel, Mira, 1991. 'The function of accessibility in a theory of grammar', Journal of Pragmatics. 16: 141-161.

BAsCom, Burton, 1982. 'Northern Tepehuan', In, R. W. Langacker (ed.), UtoAztecan grammatical sketches: Studies in Uto-Aztecan grammar 3. Summer 
Institute of Linguistics Publications in Linguistics, 56(3). Dallas: Summer Institute of Linguistics and the University of Texas at Arlington. 267-393.

BARĐDAL, JohANNA, 2001. 'The semantics of the impersonal construction in Icelandic, German and Faroese: beyond thematic roles', in W. Abraham (ed), Focus on Germanic Typology Amsterdam: John Benjmains. 106-135.

Bauer, Briggite, 2000. Archaic Syntax in Indo-European: the Spread of Transitivity in Latin and French. Berlin: de Gruyter.

Blevins, James P, 2003. 'Passives and impersonals', Journal of Linguistics 39. 473520.

Bresnan, JoAn, 2001. Lexical Functional Grammar. Oxford: Blackwell.

Burzio, Luigi, 1986. Italian Syntax. Doredrecht: Reidel.

Chomsky, Noam, 1995. The Minimalist Program, Cambridge, MA: MIT Press.

Chomsky, Noam, 2000. 'Minimalist inquiries', in Roger Martin, David Michaels and Juan Uriagereka (eds.), Step by Step: Essays on Minimalist Syntax in Honor of Howard Lasnik, Cambridge, MA: MIT Press, 89-156.

Chomsly, Noam, 2001. 'Derivation by phase', in Michael Kenstowicz (ed.), Ken Hale: A Life in Language, Cambridge, MA: MIT Press, 1-52.

CHOMsky, NoAm, 2005. 'Three factors in language design', Linguistic Inquiry 36, 122.

Cinque, Guglielmo 1988. 'On Si constructions and the theory of arb', Linguistic Inquiry 19, 521-581.

Croft, William, 2001. Radical Construction Grammar. Syntactic Theory in Typological Perspective. Oxford: Oxford University Press.

Donohue, Mark \& Soren Wichmann (eds). 2008. Typology of languages with semantic alignment. Oxford: Oxford University Press.

Egerland, Verner 2003. 'Impersonal pronouns in Scandinavian and Romance', Working Papers in Scandinavian Syntax 71, Department of Scandinavian Languages, University of Lund, 75-103.

GAIR, JAMES W., 1990. 'Subjects, cases, and INFL in Sinhala', in M. Verma and K.P. Mohanan (eds), Experiencer Subjects in South Asian Languages, Stanford: Centre for the Study of Language and Information, 13-41.

Goldberg, Alice, 1995. Constructions: A Construction Grammar Approach to Argument Structure. Chicago: Chicago University Press.

Goldberg, Alice, 2006. Constructions at work.: the nature of generalization in language. Oxford: Oxford University Press.

Givón, Talmy, 2001. Syntax. A Functional-Typological Introduction, vol. 2. John Benjamins, Amsterdam.

Hermon, Gabriella, 2001. 'Non-canonically marked A?S in Imbabura Quechua', in A. Aikhenvald et al (eds), 149-176.

Holmberg, Anders 2005. 'Is there a little pro? Evidence from Finnish', Linguistic Inquiry 36(4), 533-564.

Holmberg, Anders to appear. 'The null generic subject pronoun in Finnish', in E. Kaiser, K. Hiietam, S. Manninen \& V. Vihman (eds),. Passives and impersonals in European languages Amsterdam/Philadelphia: John Benjamins.

KAŃSKI, ZBIGNIEW, 1992. 'Impersonal constructions as a strategy for second-order predication', in Michel Kefer \& Johan van derAuwera (eds.), Meaning and grammar. Cross-linguistic Perspectives, Berlin: Mouton de Gruyter.

KAYNE, Richard S., 1993. 'Towards a modular theory of auxiliary selection', Studia Linguistica 47, 3-31.

Lambert, Pierre-Yves, 1998. 'L'impersonnel', in J. Feuillet (ed.). Actance et valence dans les Langues de l'Europe. Berlin: Mouton, 295-347.

Langacker, Ronald 1991. Foundations of Cognitive Grammar. Vol. II: Descriptive application. Standford: Stanford University Press. 
Lazard, Gilbert. 1994. L'actance. Paris: Presses Universitaires de France.

LazArd, Gilbert. 1998. Actancy. Berlin: Mouton de Gruyter.

Malchukov, Andres, 2007. 'Split intransitives, experiencer objects and 'transimpersonal' constuctions: (re-)establishing the connection', in $\mathrm{M}$. Donohue and S. Wichmann (eds), 1-32.

Malchukov, Andrej and Ann Siewierska (forthcoming). Impersonal constructions: cross-linguistic perspectives. Papers from the Workshop on Impersonal constructions, Societas Linguistica Europea, Forli, $18^{\text {th }}$ September 2008.

Seefranz-Montag, Ariane von, 1984. 'Subjectless sentences and syntactic change', in: J. Fisiak (ed.). Historical syntax. Berlin: Mouton de Gruyter, 521-533.

Siewierska, AnNa, 2007. 'Ways of impersonalizing: pronominal vs. verbal Strategies', in Lachlan Mackenzie, Anne-Marie Simon-Vandenbergen, Elsa Gonzáles Alvare María de los Angele Gomez- González (eds), Languages and cultures in contrast and comparison. Amsterdam John Benjamins, 27-61.

SŁoń, Anna, 2003. Impersonal Constructions in English and Polish. A cognitive Grammar Approach. Ph.D. Dissertation, Maria Curie-Skłodowska University in Lublin.

Sun, HongkaI, 1982. Dŭlóngŭ Jiănzhü [A brief description of the Dulong Langauge]

SUN, JACKON T-S (to appear) 'Linguistic coding of generic human arguments in rGyalrongic languages', Linguistic Typology.

TorN-LeEsiK, ReELi 2007. 'The voice system of Estonian', ms. University of Tartu.

ZIV, YAEL, 1982. 'Getting more mileage out of existentials in English'. Linguistics 20, 7: $747-762$. 


\section{Please correct and return this set}

Please use the proof correction marks shown below for all alterations and corrections. If you wish to return your proof by fax you should ensure that all amendments are written clearly in dark ink and are made well within the page margins.

\begin{tabular}{|c|c|c|}
\hline Instruction to printer & Textual mark & Marginal mark \\
\hline Leave unchanged & ... under matter to remain & ( ) \\
\hline $\begin{array}{l}\text { Insert in text the matter } \\
\text { indicated in the margin }\end{array}$ & $h$ & $\begin{array}{l}\text { New matter followed by } \\
h \text { or } h \otimes\end{array}$ \\
\hline Delete & $\begin{array}{l}\text { I through single character, rule or underline } \\
\text { or }\end{array}$ & $\sigma$ or $\sigma(x)$ \\
\hline $\begin{array}{l}\text { Substitute character or } \\
\text { substitute part of one or } \\
\text { more word(s) }\end{array}$ & I through letter or & $\begin{array}{l}\text { new character / or } \\
\text { new characters / }\end{array}$ \\
\hline Change to italics & — under matter to be changed & $\leftarrow$ \\
\hline Change to capitals & $\equiv$ under matter to be changed & $\equiv$ \\
\hline Change to small capitals & $=$ under matter to be changed & $=$ \\
\hline Change to bold type & $\sim$ under matter to be changed & $\sim$ \\
\hline Change to bold italic & $\bar{\sim}$ under matter to be changed & $\underline{s i n}$ \\
\hline Change to lower case & Encircle matter to be changed & $\Rightarrow$ \\
\hline Change italic to upright type & (As above) & \\
\hline Change bold to non-bold type & (As above) & \\
\hline Insert 'superior' character & $\begin{array}{l}/ \text { through character or } \\
K \text { where required }\end{array}$ & $\begin{array}{l}y^{\prime} \text { or } y \\
\text { under character } \\
\text { e.g. } y^{2} \text { or } y^{2}\end{array}$ \\
\hline Insert 'inferior' character & (As above) & $\begin{array}{l}\lambda \\
\text { over character } \\
\text { e.g. } \hat{\Sigma}\end{array}$ \\
\hline Insert full stop & (As above) & $\odot$ \\
\hline Insert comma & (As above) & , \\
\hline Insert single quotation marks & (As above) & $\begin{array}{l}\dot{y} \text { or } \dot{x} \text { and/or } \\
\dot{y} \text { or } \dot{y}\end{array}$ \\
\hline Insert double quotation marks & (As above) & $\begin{array}{l}\ddot{y} \text { or } \ddot{y} \text { and/or } \\
\ddot{y} \text { or } \ddot{y}\end{array}$ \\
\hline Insert hyphen & (As above) & 1 \\
\hline Start new paragraph & 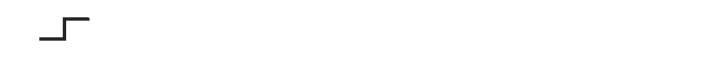 & 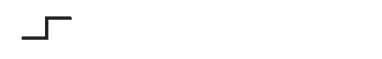 \\
\hline No new paragraph & $\infty$ & $\omega$ \\
\hline Transpose & $\sqcup$ & $\sqcup$ \\
\hline Close up & linking $\bigcirc$ characters & \\
\hline $\begin{array}{l}\text { Insert or substitute space } \\
\text { between characters or words }\end{array}$ & $\begin{array}{l}\text { I through character or } \\
\Lambda \text { where required }\end{array}$ & \\
\hline $\begin{array}{l}\text { Reduce space between } \\
\text { characters or words }\end{array}$ & $\begin{array}{l}\text { between characters or } \\
\text { words affected }\end{array}$ & $\uparrow$ \\
\hline
\end{tabular}

